\title{
Carpinus betulus pollen accumulation rates in Roztocze (SE Poland) in relation to presence of Carpinus in Ferdynandovian pollen diagrams
}

\author{
Irena Agnieszka Pidek \\ Faculty of Earth Sciences and Spatial Management, Maria Curie-Skłodowska University, al. Kraśnicka 2 c/d, \\ 20-718 Lublin, Poland; \\ e-mail: i.pidek@poczta.umcs.lublin.pl
}

Received: 05 May 2017/Accepted: 03 June 2017

\begin{abstract}
Carpinus pollen has been recorded in fossil pollen diagrams of different interglacials. In case of the Ferdynandovian pollen sequence it is of particular importance to know if scattered presence of Carpinus pollen at the decline of Ferdynandovian 1 interglacial represents long distance transport of pollen or small isolated Carpinus populations. The study aims to trace the pollen-vegetation relationship in Roztocze (SE Poland) using Tauber-style pollen traps to understand better the pattern of Carpinus pollen dispersal and deposition. High and low pollen deposition years were recorded for Carpinus betulus in the period 1998-2010. Deposition was extremely high in 2002. Average annual pollen accumulation rate was calculated at 1348 grains cm $^{-2}$ year $^{-1}$, which was $4.1 \%$ of total pollen spectrum. The study confirms that the earlier pollen presence/absence threshold values of about $5 \%$ for the presence of Carpinus trees in vegetation (Huntley \& Birks 1983) were too high. The pollen monitoring data from Roztocze support the opinion of Ralska-Jasiewiczowa et al. (2004) that low values of about $0.5 \%$ may reflect the presence of Carpinus trees in the forests. These data, in comparison to the scattered Carpinus pollen grains in the last part of the Ferdynandovian 1 interglacial seem to indicate that single trees of this genus may nave occurred in the vegetation at the decline of interglacial optimum.
\end{abstract}

Keywords: Carpinus betulus, pollen monitoring, pollen deposition, fossil pollen diagrams, Ferdynandovian

\section{Introduction}

Pollen diagrams of different interglacials include Carpinus percentage pollen curves in Poland.The pattern of its occurrence differs significantly between Ferdynandovian/ Cromerian, Mazovian/Holsteinian and Eemian interglacials (Mamakowa 2003). In the well-recognized interglacial pollen successions, including the Holocene, Carpinus usually occurs in the second part of interglacial optimum. The only exception is the first interglacial (F1) within the Ferdynandovian (=Cromerian) succession (Mamakowa 2003; Pidek 2013, 2015; Pidek \& Poska 2013) in which Carpinus either does not occur at all, or occurs only in sporadic pollen grains at the very decline of climatic optimum (Fig. 1).
There is a matter of debate if this unusual occurrence indicates small scattered Carpinus populations or rather a long distance transport from sources situated far to the south.

Studies of modern pollen deposition of trees conducted in the Roztocze in the years 1998-2010 aim to trace pollen dispersal and deposition of main forest forming species of the Roztocze region, including Carpinus betulus. This tree is a central European element growing mainly in lowland conditions and in the highlands. In the mountains it usually does not reach altitudes above 700-1000 m a.s.1. Carpinus is an important element of the multispecies broadleaved forests and a species characteristic for the Carpinion betuli alliance (Boratyńska 1993). Faliński \& Pawlaczyk (1993) suggest that the lack of sufficient warmth for seeds devel- 


\section{FERDYNANDÓW 2011}

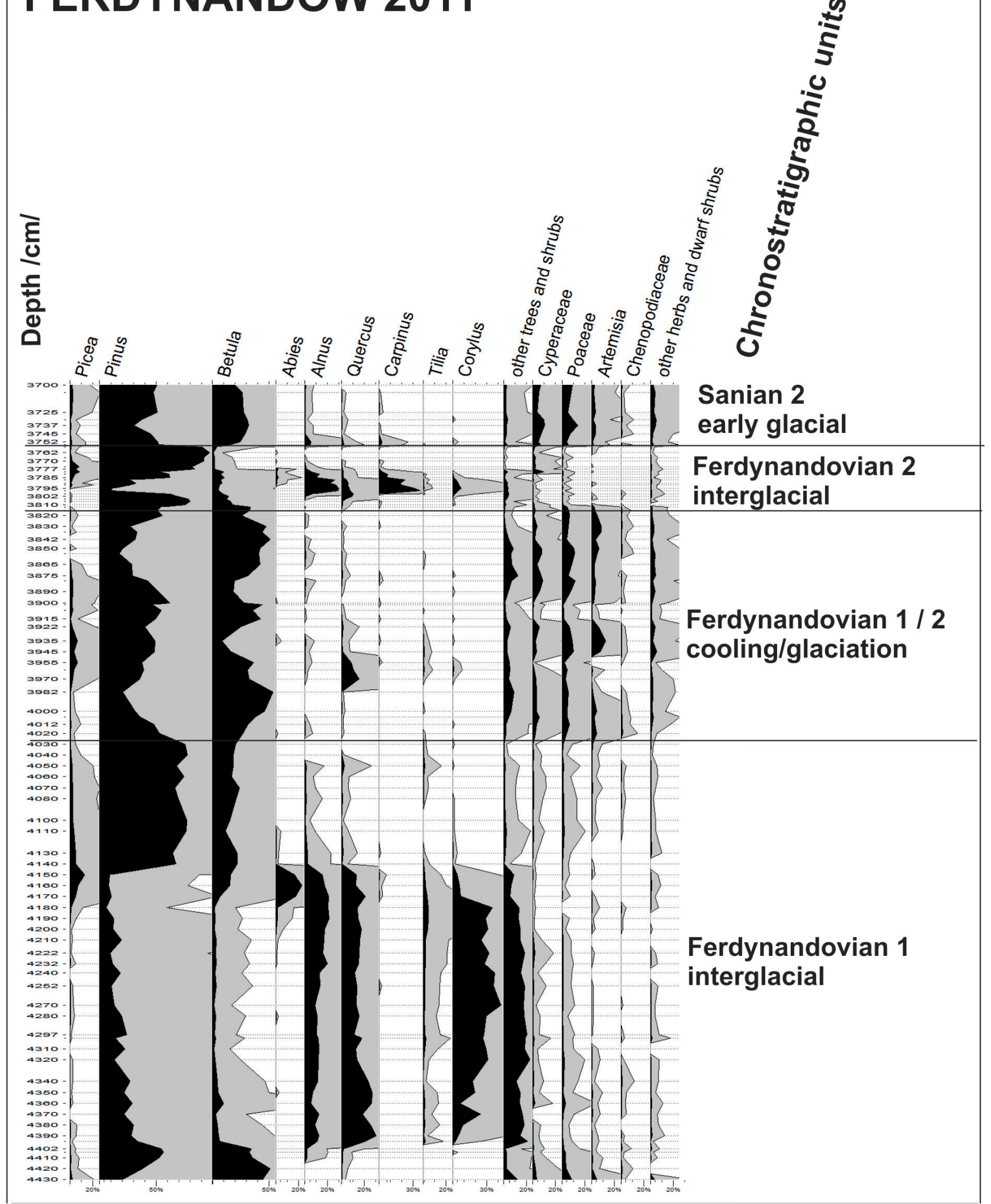

Figure 1. Simplified pollen diagram of Ferdynandovian pollen sequence in the stratotype profile Ferdynandów 2011, based on fossil pollen data by Pidek (2015). Chronostratigraphic units follow Lindner et al. (2004). For the drawing of the diagram the POLPAL software was used (Nalepka \& Walanus 2003). 
opment during late spring limits its distribution in the east. Carpinus betulus flowers in Poland between the end of April and the first half of May (Tomanek 1994).

Pollen Accumulation Rates (PAR) for Carpinus in Roztocze were traced in different situations according to the Pollen Monitoring Programme guidelines (Hicks et al. 1996; www.pollentrapping.org). These include 9 pollen trapping sites, among which there are traps located inside the forest, at the forest edge and in open situations. Detailed characteristics of pollen trapping sites are provided in Pidek (2004). The data series 1998-2010 has been analysed by van der Knaap et al. (2010) in terms of pollenclimate correlations and used to trace natural physiological rhythmicity in abundant flowering of tree species (Pidek et al. 2015).

The present study aims at calculating average Pollen Accumulation Rates (PAR) and percentages of Carpinus in relation to total pollen spectra in different vegetation situations in Roztocze in order to use these data to interpret presence or absence of Carpinus in the forests at the decline of Ferdynandovian 1 interglacial.

\section{Study area}

The Roztocze region forms an elevated highland area of the width of about $28 \mathrm{~km}$ in south-eastern Poland at the border between Poland and Ukraine. The region is characterized by rich multispecies forests of natural character in the central part of the area, which are protected within the
Roztocze National Park. Fir-tree forests (Abietetum polonicum) cover the lower and middle parts of the slopes, while Carpathian beech forests (Dentario glandulosae-Fagetum) cover the uppermost ones (Izdebski et al. 1992). Forests of Tilio-Carpinetum association are located mainly in gullies unsuitable for farming. Large areas overgrown by different pine communities occur on dunes and plains.

Nine pollen trapping sites are located around Guciów village in the protected zone of the Roztocze National Park. Carpinus is one of the main components of TilioCarpinetum association in the Park $(2.8 \%$ of the Park area, Izdebski et al. 1992) and in the Guciów village (4.0\% of the village area, Grądziel et al 2006). Carpinus is also a very important tree in substitute communities from the Querco-Fagetea class, where it occurs in lower tree layer and at the forest edge. The proportion of these communities in the Park is $23.7 \%$, while in the Guciów village $4.7 \%$.

\section{Methods}

Annual pollen accumulation rates (PARs) have been monitored with the use of Tauber-style traps according to the guidelines by Hicks et al. (1996). The pollen trapping sites are located in different situations (Table 1), i.e. from closed forest through the forest edge to open landscape, according to the guidelines of the Pollen Monitoring Programme (PMP; www.pollentrapping.org; Giesecke et al. 2010; Poska 2013). The annual pollen deposited in a trap over a year is subject to laboratory treatment with the

Table 1. Description of traps location in the Roztocze region and the distance to nearest Carpinus trees.

\begin{tabular}{|c|c|c|c|}
\hline $\begin{array}{c}\text { Trap } \\
\text { no }\end{array}$ & Description of trap location & Size of the forest opening & $\begin{array}{c}\text { Distance } \\
\text { to nearest } \\
\text { Carpinus } \\
\text { tree }\end{array}$ \\
\hline G 1 & Small opening within Abietetum polonicum & $10 \times 10 \mathrm{~m}$ & $200 \mathrm{~m}$ \\
\hline G 2 & $\begin{array}{l}\text { Large opening within mixed pine-deciduous } \\
\text { forest }\end{array}$ & $40 \times 120 \mathrm{~m}$ & $40 \mathrm{~m}$ \\
\hline G 3 & $\begin{array}{l}\text { Meadow on edge of mixed forest with Pinus and } \\
\text { Abies as dominant trees }\end{array}$ & $\begin{array}{l}\text { Forest edge - distance from nearest trees ca. } \\
25 \mathrm{~m} \text { from eastern side }\end{array}$ & $25 \mathrm{~m}$ \\
\hline G 4 & $\begin{array}{l}\text { Large clearing within mixed Pinus-Betula forest } \\
\text { with admixture of other tree species }\end{array}$ & $60-120 \mathrm{~m}$ & $60 \mathrm{~m}$ \\
\hline G 5 & $\begin{array}{l}\text { Meadow on edge of Dentario glandulosae- } \\
\text { Fagetum }\end{array}$ & $\begin{array}{l}\text { Forest edge }- \text { distance from nearest trees } \\
2 \mathrm{~m} \text { from western side }\end{array}$ & $1 \mathrm{~m}$ \\
\hline G 6 & $\begin{array}{l}\text { Open vegetation - abandoned field overgrown by } \\
\text { Betula and Salix }\end{array}$ & Open vegetation & $400 \mathrm{~m}$ \\
\hline G 7 & $\begin{array}{l}\text { Open vegetation - meadow within cultivated and } \\
\text { abandoned fields }\end{array}$ & $\begin{array}{l}\text { Open vegetation, patch of pine and birch from } \\
\text { eastern side at a distance of ca. } 15 \mathrm{~m}\end{array}$ & $500 \mathrm{~m}$ \\
\hline G 8 & Large clearing within beech forest & $80 \times 100 \mathrm{~m}$ & $40 \mathrm{~m}$ \\
\hline G 9 & Under canopy site within beech forest & $\begin{array}{l}\text { Under canopy site, distance from nearest trees } \\
\qquad 8 \mathrm{~m}\end{array}$ & $30 \mathrm{~m}$ \\
\hline
\end{tabular}


addition of Lycopodium tablets (Stockmarr 1971), then filtering and Erdtman's acetolysis. The number of pollen grains of each taxon deposited on a surface of $1 \mathrm{~cm}^{2}$ is calculated as PAR. Counting under a light microscope is continued until a minimum of 500 tree pollen grains and at least 100 Lycopodium spores is obtained. Average annual PAR was calculated for Carpinus based on pollen accumulation data from all the traps in the Roztocze region (Table 2 ).

\section{Results}

Pollen traps were placed in different types of plant communities (Table 1) including small forest openings (trap G 1 and G 9), large forest openings (traps G 2, G 4 and G 8), forest edges with abundant hornbeam trees (traps G 3 and G 5) and open situations of abandoned arable fields (traps $\mathrm{G} 6$ and $\mathrm{G} 7$ ).

The closest distance to Carpinus trees 1-25 m were observed in trapping sites G 5 and G 3. In these two cases Carpinus forms forest edge and the values of average PARs are high, i.e. $3340{\text { grains } \mathrm{cm}^{-2} \text { year }}^{-1}(11.7 \%)$ and 1123 (2.8\%), respectively. Quite high values were also obtained for traps G 4 and G 9 - 1901 (4.6\%) and 1319 (3.9\%), respectively; where the distance to Carpinus trees is bigger, but the forest edge is composed of this tree, too. The lowest average PARs were obtained for traps in open landscape (abandoned fields, traps nos G 6 and G 7), in which the distance to nearest Carpinus trees was 400-500 m. In these two cases average PAR ranges from 573 (trap G7) to 737 grains $\mathrm{cm}^{-2}$ year $^{-1}$ (trap G 6) (or $1.7 \%$ in each case). The

Table 2. Carpinus PAR and percentages in pollen traps in Roztocze (1998-2010).

\begin{tabular}{|c|c|c|c|c|c|c|c|c|}
\hline $\begin{array}{c}\text { Trap no/ } \\
\text { year }\end{array}$ & PAR & $\%$ & $\begin{array}{c}\text { Trap no/ } \\
\text { year }\end{array}$ & PAR & $\%$ & $\begin{array}{c}\text { Trap no/ } \\
\text { year }\end{array}$ & PAR & $\%$ \\
\hline G 1/2010 & 360 & 1.5 & G 4/2010 & 3421 & 7.7 & G 7/2010 & 687 & 2.0 \\
\hline G 1/2009 & - & - & G 4/2009 & 1071 & 2.6 & G 7/2009 & 209 & 1.0 \\
\hline G $1 / 2008$ & 254 & 1.4 & G 4/2008 & 1216 & 1.8 & G 7/2008 & 209 & 0.6 \\
\hline G 1/2007 & 886 & 3.0 & G 4/2007 & 3624 & 9.6 & G 7/2007 & 681 & 2.5 \\
\hline G 1/2006 & - & - & G 4/2006 & 2169 & 6.7 & G 7/2006 & 554 & 1.5 \\
\hline G 1/2005 & 196 & 1.6 & G 4/2005 & - & - & G 7/2005 & 376 & 1.2 \\
\hline G 1/2004 & 116 & 0.3 & G 4/2004 & 509 & 1.6 & G 7/2004 & 157 & 0.8 \\
\hline G $1 / 2003$ & 363 & 2.1 & G 4/2003 & 1130 & 2.8 & G 7/2003 & 565 & 0.9 \\
\hline G 1/2002 & - & - & G 4/2002 & 4913 & 9.2 & G 7/2002 & 1751 & 4.9 \\
\hline G 1/2001 & 307 & 1.6 & G 4/2001 & 1291 & 5.2 & G 7/2001 & 512 & 1.5 \\
\hline G 1/2000 & 148 & 1.4 & G 4/2000 & 471 & 3.2 & G 7/2000 & - & - \\
\hline G 1/1999 & 521 & 2.7 & G 4/1999 & 1044 & 2.7 & G 7/1999 & 605 & 2.3 \\
\hline G 1/1998 & - & - & G 4/1998 & 1958 & 2.3 & G 7/1998 & - & - \\
\hline Average & 350 & 1.7 & Average & 1901 & 4.6 & Average & 573 & 1.7 \\
\hline G 2/2010 & 1279 & 4.2 & G 5/2010 & 5502 & 13.4 & G 8/2010 & 1318 & 2.2 \\
\hline G 2/2009 & 554 & 2.6 & G 5/2009 & 712 & 3.5 & G 8/2009 & - & - \\
\hline G 2/2008 & 1180 & 3.6 & G 5/2008 & - & - & G 8/2008 & 1909 & 2.8 \\
\hline G 2/2007 & 1397 & 5.8 & G 5/2007 & 2125 & 9.2 & G 8/2007 & 1853 & 6.0 \\
\hline G 2/2006 & 1449 & 5.2 & G 5/2006 & 6860 & 21.8 & G 8/2006 & 3560 & 9.7 \\
\hline G 2/2005 & 785 & 3.3 & G 5/2005 & 692 & 4.2 & G 8/2005 & 1285 & 2.9 \\
\hline G 2/2004 & 454 & 1.2 & G 5/2004 & 1389 & 7.2 & G 8/2004 & 721 & 2.8 \\
\hline G 2/2003 & 396 & 1.2 & G 5/2003 & 1141 & 3.6 & G 8/2003 & 719 & 2.0 \\
\hline G 2/2002 & 2797 & 5.9 & G 5/2002 & 7439 & 19.5 & G 8/2002 & 4374 & 11.3 \\
\hline G 2/2001 & 408 & 1.2 & G 5/2001 & 1861 & 6.7 & G 8/2001 & - & - \\
\hline G 2/2000 & 467 & 3.0 & G 5/2000 & 480 & 2.9 & G 8/2000 & 640 & 1.8 \\
\hline G 2/1999 & 878 & 6.0 & G 5/1999 & 8547 & 36.5 & G 8/1999 & 752 & 6.3 \\
\hline
\end{tabular}




\begin{tabular}{|c|c|c|c|c|c|c|c|c|c|c|}
\hline $\begin{array}{c}\text { Trap no/ } \\
\text { year }\end{array}$ & PAR & $\mathbf{\%}$ & & $\begin{array}{c}\text { Trap no/ } \\
\text { year }\end{array}$ & PAR & $\mathbf{\%}$ & & $\begin{array}{c}\text { Trap no/ } \\
\text { year }\end{array}$ & PAR & $\%$ \\
\hline G 2/1998 & - & - & & G 5/1998 & - & - & & G 8/1998 & - & - \\
\hline Average & $\mathbf{1 0 0 3}$ & $\mathbf{3 . 6}$ & & Average & 3340 & 11.7 & & Average & 1713 & 4.8 \\
\hline & & & & & & & & & & \\
\hline G 3/2010 & 1650 & 4.0 & & G 6/2010 & 793 & 1.4 & & G 9/2010 & 1416 & 4.0 \\
\hline G 3/2009 & 599 & 1.5 & & G 6/2009 & 310 & 1.4 & & G 9/2009 & 685 & 3.5 \\
\hline G 3/2008 & 458 & 1.6 & & G 6/2008 & 212 & 0.4 & & G 9/2008 & - & - \\
\hline G 3/2007 & 3923 & 8.6 & & G 6/2007 & 1178 & 3.0 & & G 9/2007 & 1983 & 6.5 \\
\hline G 3/2006 & 1207 & 3.3 & & G 6/2006 & 1240 & 2.7 & & G 9/2006 & 2037 & 3.7 \\
\hline G 3/2005 & 283 & 1.6 & & G 6/2005 & 441 & 1.4 & & G 9/2005 & - & - \\
\hline G 3/2004 & 467 & 2.3 & & G 6/2004 & 324 & 1.1 & & G 9/2004 & 871 & 2.5 \\
\hline G 3/2003 & 985 & 3.3 & & G 6/2003 & 507 & 1.1 & & G 9/2003 & - & - \\
\hline G 3/2002 & 2749 & 5.3 & & G 6/2002 & 1874 & 3.8 & & G 9/2002 & 3378 & 10.5 \\
\hline G 3/2001 & 733 & 1.0 & & G 6/2001 & 132 & 0.2 & & G 9/2001 & 47 & 0.3 \\
\hline G 3/2000 & 178 & 1.0 & & G 6/2000 & - & - & & G 9/2000 & 215 & 0.8 \\
\hline G 3/1999 & 620 & 1.6 & & G 6/1999 & 886 & 2.6 & & G 9/1999 & 1247 & 3.6 \\
\hline G 3/1998 & 758 & 1.9 & & G 6/1998 & 957 & 1.8 & & G 9/1998 & - & - \\
\hline Average & $\mathbf{1 1 2 3}$ & $\mathbf{2 . 8}$ & & Average & 737 & 1.7 & & Average & 1319 & 3.9 \\
\hline
\end{tabular}

average annual PAR based on all the traps in the period 1998-2010 was about 1348 grains $\mathrm{cm}^{-2}$ year ${ }^{-1}$

The average annual PARs for Carpinus are comparable to the ones calculated by Pidek et al. (2015) for Alnus and Fagus (ca. 1300-1400, respectively) and much lower than the values of PARs recorded for Pinus and Betula (ca. 6000 and 5000 pollen grains $\mathrm{cm}^{-2}$ year ${ }^{-1}$, respectively).

In the Carpinus pollen data series (Table 2, Fig. 2) large year to year variation in pollen accumulation rates (PARs) was observed.

The highest PAR values were recorded in 2002, while for most other tree species in Roztocze 2003 was recorded as an exceptionally high pollen deposition year (Pidek et al. 2015). Other years of high pollen deposition of Carpinus were 2006, 2007 and 2010. 1999 can be considered as a high year in several traps. In general, the 2006 was extremely high year also for Picea, Fagus, Fraxinus, Ulmus, Betula and Alnus,

Low years for Carpinus pollen deposition were 2000, 2005 and 2009. In general, the year 2000 was also low for Pinus, Alnus and Quercus, and 2005 year - for Pinus, Picea and Alnus, and 2009 year for Fagus, Abies, Ulmus, Alnus, Betula and Fraxinus.

In terms of percentages the average value for Carpinus pollen in pollen spectra from Roztocze is about $4.1 \%$. It seems comparable with the proportion of this tree or representation in the vegetation if we calculate only TilioCarpinetum association in the Park and in the Guciów village $(2.8 \%-4.0 \%)$. However, in relation to percentage representation of substitute communities from the QuercoFagetea class with frequent Carpinus at the forest edges; i.e. $23.7 \%$ in the Park and $4.7 \%$ in the Guciów village, it is clear that Carpinus is underrepresented in pollen assemblages. These conclusions agree with Ralska-Jasiewiczowa et al. (2004), who found that values as low as $0.5 \%$ in the Holocene pollen assemblages probably indicated the presence of Carpinus trees in the forests. The study confirms that the earlier pollen presence/absence threshold values of about $5 \%$ for the presence of hornbeam trees in vegetation (Huntley, Birks 1983) were too high.

\section{Acknowledgements}

The author is grateful to dr Heather Pardoe for her valuable comments for the earlier version of the manuscript. This study is a contribution to the Pollen Monitoring Programme (http://www.pollentrapping.org). The work was partially financed by research funds granted by the Polish Ministry of Science and Higher Education for the Faculty of Earth Sciences and Spatial Management UMCS. 


\section{References}

Boratyńska K., 1993, Systematyka i rozmieszczenie geograficzne, [in:] Grab zwyczajny - Carpinus betulus L. [Hornbeam], W. Bugała (ed.) Nasze drzewa leśne, Monografie popularnonaukowe, [Our forest trees. Monographic study] 9, Poznań-Kórnik, Sorus, Poland: $17-50$.

Faliński B.J. \& Pawlaczyk P., 1993, Zarys ekologii. [in:] Grab zwyczajny - Carpinus betulus L. [Hornbeam].W. Bugała (ed.) Nasze drzewa leśne. Monografie popularnonaukowe, [Our forest trees. Monographic study] 9, Poznań-Kórnik, Sorus, Poland: 157-263.

Giesecke T., Fontana S.L., van der Knaap W.O., Pardoe H.S. \& Pidek I.A., 2010, From early pollen trapping experiments to the Pollen Monitoring Programme, Vegetation History and Archaeobotany 19(4): 247-258.

Grądziel T., Janicki G., Furtak T., Pidek I.A. \& Rodzik J., 2006, Ocena stopnia naturalności i kierunków przekształceń roślinności w oparciu o metody: fitosocjologiczną i krajobrazową (na przykładzie wsi Guciów na Roztoczu Środkowym). Regionalne Studia Ekologiczno-Krajobrazowe. Problemy Ekologii Krajobrazu t.16, Wyd. Polska Asocjacja Ekologii Krajobrazu, Warszawa, cz. I: 401-412.

Hicks S., Ammann B., Latałowa M., Pardoe H. \& Tinsley H., 1996, European Pollen Monitoring Programme, Project Description and Guidelines, Oulu University Press, Oulu, Finland.

Huntley B. \& Birks J., 1983, An Atlas of past and present pollen maps for Europe: 0-13000 years ago, Cambridge University Press, Cambridge.

Izdebski K., Czarnecka B., Grądziel T., Lorens B. \& Popiołek Z., 1992, Plant communities against the background of the Roztocze National Park habitat conditions, Maria Curie-Skłodowska University Press, Lublin, Poland.

Lindner L., Gozhik P., Marciniak B., Marks L. \& Yelovicheva Y., 2004, Main climatic changes in the Quaternary of Poland, Belarus and Ukraine, Geological Quarterly 48(2): 97-114.

Mamakowa K., 2003, Plejstocen. [in:] Palinologia, S. Dybova-Jachowicz, A. Sadowska (eds.) Wyd. IB PAN, Kraków: 235-266.
Nalepka D. \& Walanus A., 2003, Data processing in pollen analysis, Acta Palaeobotanica 43: 125-134.

Pidek I.A., 2004, Preliminary results of pollen trapping in the region of the Roztocze National Park (SE Poland), Annales UMCS, Lublin, sec. B, 49: 143-159.

Pidek I.A., 2013, Pollen-based vegetation and climate reconstruction of the Ferdynandovian sequence from Łuków (E Poland), Acta Palaeobotanica 53(1): 115138.

Pidek I.A., 2015, Palynostratigraphy and vegetation changes during the early Middle Pleistocene, based on new studies of deposits from Ferdynandów (central eastern Poland), Acta Palaeobotanica 55(1): 53-66.

Pidek I.A. \& Poska A., 2013, Pollen based quantitative climate reconstructions from the Middle Pleistocene sequences at Łuków and Zdany (E Poland): species and modern analogues based approach, Review of Palaeobotany and Palynology 192: 65-78.

Pidek I.A., Poska A. \& Kaszewski B.M., 2015, Taxon-specific pollen deposition dynamics in a temperate forest zone, SE Poland: the impact of physiological rhythmicity and weather controls, Aerobiologia 31(2): 219-238

Poska A., 2013, Pollen Methods and studies: Surface Samples and Trapping. [in:] Encyclopedia of Quaternary Science (Second Edition), Scott A. Elias and Cary J. Mock, Elsevier, Amsterdam: 839-845.

Ralska-Jasiewiczowa M., Miotk-Szpiganowicz G., Zachowicz J., Latałowa M. \& Nalepka D., 2004, Carpinus betulus L. - Hornbeam. [in:] Late Glacial and Holocene history of vegetation in Poland based on isopollen maps, M. Ralska-Jasiewiczowa et al. (eds.), W. Szafer Institute of Botany, Polish Academy of Sciences, Kraków: 69-78.

Stockmarr J., 1971, Tablets with spores used in absolute pollen analysis. Pollen et Spores 13: 615-621.

Tomanek J., 1994, Botanika leśna [Forest botany]. Państwowe Wydawnictwa Rolnicze i Leśne, 5 ed, Warszawa, Poland.

van der Knaap W.O., van Leeuven J.F.N., Svitavská-Svobodová H., Pidek I.A., Kvavadze E., Chichinadze M., Giesecke T., Kaszewski B.M., Oberli F., Kalniņa L., Pardoe H.S., Tinner W. \& Ammann B., 2010, Annual pollen traps reveal the complexity of climatic control on pollen productivity in Europe and the Caucasus, Vegetation History and Archaeobotany, 19(4): 285-307. 


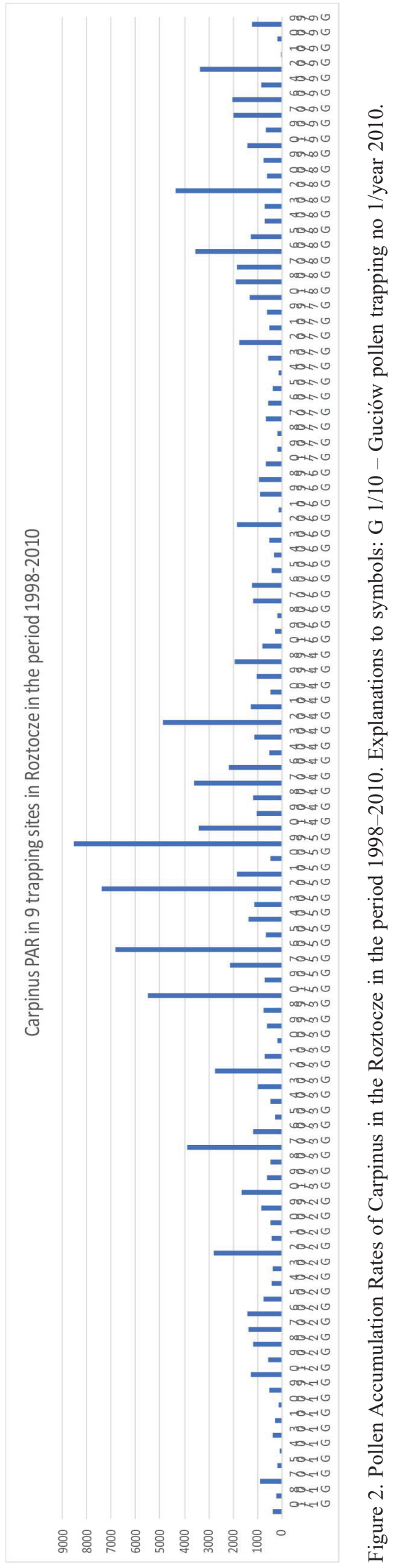

